\title{
An integrative eco-evo-devo framework identifies complex drivers of oral morphology in tailed frog (Ascaphus spp.) tadpoles
}

\author{
AS Cicchino* ${ }^{* 1,2}$, CM Martinez $^{* 1}$, WC Funk $^{1,2}$, BR Forester $^{1}$
}

* These authors contributed equally

${ }^{1}$ Department of Biology, Colorado State University, 1878 Campus Delivery, Fort Collins, CO 80523 USA

${ }^{2}$ Graduate Degree Program in Ecology, Colorado State University, 1878 Campus Delivery, Fort Collins, CO 80523 USA

Correspondence: AS Cicchino (cicchino@colostate.edu)

\section{Acknowledgements}

For assistance with data collection and field logistics, we thank A.A. Shah, D. Oliver, L. King, A. Breda, J. Suh, K. Pain, R. Gimple, J. Kendrick, R. Jackson, R. Murray, W. Palen, B. Hossack, and W. Lowe. We also thank the Devo-Evo discussion group led by Kim Hoke, Rachel Mueller, and Ashok Prassad for thoughtful discussions regarding development and evolution. We acknowledge funding from a National Science Foundation (NSF) Rules of Life grant (1838282) to W. Chris Funk and a Natural Sciences and Engineering Research Council of Canada (NSERC) post-graduate scholarship to Amanda S. Cicchino (PGSD2-532408-2019).

\section{Author Contributions}

All authors conceived the ideas and designed methodology; ASC and CM collected the data; ASC and BRF analyzed the data; ASC led the writing of the manuscript, with contributions from $\mathrm{CM}$ and BRF. All authors contributed critically to the drafts and gave final approval for publication.

\section{Data Availability Statement}

Data for this manuscript will be deposited to Dryad upon acceptance. 


\begin{abstract}
1. Morphological variation is often maintained by complex and interrelated factors, complicating the identification of underlying drivers. Comprehensive understanding of the evolution of morphological traits thus requires the use of integrative methods that can simultaneously investigate potentially interacting drivers.
\end{abstract}

2. Tadpole oral morphology is one such trait that may be driven by the direct and indirect effects of the environment and variation in developmental processes. Although many studies have investigated tadpole oral morphological diversity among species, few have sought to understand the drivers that underlie intraspecific variation.

3. In this study, we investigated potential drivers of labial tooth number variation among populations of two species of tailed frogs, the Rocky Mountain tailed frog (Ascaphus montanus) and the Coastal tailed frog (A. truei). We used an integrative eco-evo-devo framework to test the direct and indirect effects of developmental processes (population variation in size by developmental stage) and environmental selection (temperature) on labial tooth number across three tooth rows in 240 tadpoles.

4. Using this framework, we explained $64-81 \%$ of the variation in labial tooth number variation in three labial tooth rows for $A$. montanus and $37-54 \%$ of the variation in labial tooth number in the same tooth rows for $A$. truei. Apart from the consistent effects of tadpole length on labial tooth number, we found strong support for temperature as a direct driver for increased labial tooth number, supporting our eco-evo hypothesis in both species. In A. montanus, we also found strong support for variation in our proxy for developmental processes influencing labial tooth number variation (devo-evo), as well as the interacting effects of temperature and this developmental process proxy (i.e., developmental plasticity; eco-devo). In A. truei, we found mixed support for these latter two drivers among labial tooth rows.

5. We conclude that labial tooth number variation in tailed frogs is driven by complex and interacting environmental and developmental factors. Without the use of an interdisciplinary framework, these relationships may not have been uncovered and our ability to explain the variation in this morphological trait would have been limited.

Keywords: Amphibian, developmental plasticity, intraspecific variation, labial tooth, oral morphology, temperature 


\section{INTRODUCTION}

Determining how phenotypic variation is generated and maintained, and how it affects ecological processes is key to understanding the evolution and maintenance of biodiversity. Phenotypic variation is often a product of the interaction between intrinsic factors (e.g., genetics, development, physiology) and extrinsic factors (e.g., selection, environmental effects), complicating the identification of underlying drivers. Although integrative methods are advantageous for understanding patterns in biodiversity (Sultan, 2007; Houle et al., 2010; Gilbert et al., 2015; Sultan, 2015; Skúlason et al., 2019), many studies focus on a limited number of possible drivers, potentially missing important interactions. Effectively parameterizing existing frameworks is thus the next step for developing a deeper understanding of trait evolution.

Skúlason et al. (2019) proposed a framework for studying phenotypic variation that integrates the fields of ecology, evolution, and development with equal emphasis (eco-evo-devo), while also accounting for their reciprocal nature. For example, the environment can shape phenotypic variation directly by acting as a selective pressure (eco-evo) (Coyne and Orr, 2004), as well as indirectly through developmental plasticity (eco-devo) (Pigliucci, 2001; Sultan, 2015). The phenotypic variation mediated by these processes can also feedback to alter the environment (evo-eco; devo-eco) (Gilbert et al., 2015; Svensson, 2018; Govaert et al., 2019; Schwab et al., 2019; Skúlason et al., 2019). The evolution of variation in developmental processes, such as the rate, sequence, or timing of developmental events can also maintain phenotypic variation (devoevo; Chipman 2002) as well as reciprocally shape evolution through intrinsic processes (e.g., epigenetics). A comprehensive analysis based on this framework may be beyond the scope of many projects, as data collection is required from multiple scales of organization. This may explain why many studies to date investigate only one or two of the relationships outlined in this triad. Some systems, such as those with metamorphosing larval stages in which morphological traits are subject to developmental changes regardless of extrinsic pressures, may be particularly well-suited to the demands of these integrative methods.

Anuran (frog and toad) tadpoles are a phenotypically diverse group of organisms with complex oral morphologies that arise in response to diverse drivers. Generally, the tadpole oral apparatus consists of an oral disc with papillae and multiple rows of keratinized labial teeth (sensu Altig and McDiarmid, 1999) that surround a jaw sheath and mouth (Figure 1). These mouthparts play a critical role in feeding by both stabilizing the tadpole during feeding as well as lifting food off of substrates (Wassersug and Yamashita, 2001; Venesky et al., 2010; 2013). Oral morphology can facilitate or constrain feeding on certain substrates (Annibale et al., 2019, Annibale et al., 2020) and damage can lead to decreased feeding efficiency (Venesky et al., 2010). As such, the environment may select for certain morphologies, as has been suggested by the similarity of oral morphologies within some ecological guilds (Altig and McDiarmid, 1999; Altig, 2006; Vera Candioti and Altig, 2010). Additionally, individual rates of growth (cell differentiation) and development (cell specialization) may also vary within and among populations and can be reflected in oral morphology (Altig and McDiarmid, 1999; Conradie and Conradie, 2015). These developmental processes may also be influenced by environmental effects (i.e., developmental plasticity). For example, temperature has been shown to influence the rate of tadpole growth and development (e.g., Arendt, 2006). Vences et al. (2002) highlighted the downstream effects of this temperature-driven developmental plasticity on oral morphology using an experimental approach in tadpoles of the common frog, Rana temporaria. These authors showed that temperature effects on developmental rates led to variation in the number of labial teeth and of labial tooth rows (Vences et al., 2002). The interacting effects of the 
environment and developmental processes may shape tadpole oral morphology, making an investigation of these drivers of oral morphological traits well suited to an eco-evo-devo framework.

Tailed frog (Family: Ascaphidae) tadpoles have a distinctive oral morphology with specialized, suctorial mouthparts. The two species in this family occupy cold, fast-flowing, high gradient streams in mesic, forested landscapes of the Klamath Mountains, Coast Ranges, and Cascade Mountains (Ascaphus truei), and northern Rocky Mountains (A. montanus) of the United States and Canada (Figure 2). These tadpoles have an enlarged oral disc with a sucker and flexible papillae that attaches to stream substrate and prevents them from being washed downstream (Gradwell, 1971). Unlike many other frog species, the labial teeth do not play a role in stabilization and thus are thought to function solely in feeding kinematics along with their large, flat upper sheath (Gradwell, 1971; Altig and Johnston, 1989). Tailed frog larval development is slow (Brown, 1975 \& 1989) and variable; the tadpole stage lasts one to four years, with greater variation found across the wider latitudinal and elevational range of $A$. true $i$ (Hayes and Quinn, 2015). This variation in developmental rates may be affected by environmental conditions (Brown, 1990; Wallace and Diller, 1998; Bury and Adams, 1999). The fact that labial tooth function is fairly well understood coupled with varying developmental rates make tailed frogs an excellent system to investigate the drivers of variation in labial tooth number, a trait that has not yet been investigated in detail across multiple populations of anuran tadpoles.

In this study, we use the eco-evo-devo framework of Skúlason et al. (2019) to investigate drivers of variation in labial tooth number in these two tailed frog species, and more generally, to test the utility of this framework for obtaining a deeper understanding of phenotypic variation. We explore variation in labial tooth number as a product of selection by the environment (ecoevo), variation in developmental process (devo-evo), and as an indirect response to the environment through developmental plasticity (eco-devo). Our baseline hypothesis is that variation in the number of labial teeth is explained by tadpole length, representing variation due to scaling (Figure 3). We expect tadpole length to be positively related to labial tooth number in each row. Additionally, we hypothesize that stream temperatures will influence labial tooth number variation (eco-evo). Temperature plays a large role in many ectothermic processes, such as metabolic rate (Gillooly et al., 2001; Brown et al., 2004), rates of growth and development (Gillooly et al., 2002; Angilletta and Dunham, 2003; Angilletta et al., 2004; Gomez-Mestre et al., 2010; Liess et al., 2013), and feeding rates (De Sousa et al., 2015). As tadpoles inhabiting warmer streams may require more energy to meet metabolic demands (Gillooly et al., 2001; Liess et al., 2013) and more labial teeth may be more efficient for feeding (Venesky et al., 2010), we expect populations inhabiting warmer streams to have more labial teeth than those occupying colder streams. This relationship would be a response to environmental selection for increased feeding efficiency. Our devo-evo hypothesis is that variation in developmental processes among populations will explain variation in labial teeth number (Figure 3). For this hypothesis, we expect that populations that exhibit greater energy allocation to growth over development, measured as greater tadpole length at a given developmental stage, will have more labial teeth. Lastly, our eco-devo hypothesis is that developmental plasticity driven by local thermal regimes will influence the relationship between growth and development (Figure 3), ultimately affecting the number of labial teeth. We predict that populations occupying colder streams will have lower developmental rates as a response to temperature. These populations will thus have greater energy allocation to growth, resulting in more labial teeth than populations occupying warmer 
streams where developmental rates are expected to be greater. These hypotheses are not mutually exclusive and due to diverse ecological, evolutionary, and developmental factors affecting oral morphology, we expect to find support for more than one.

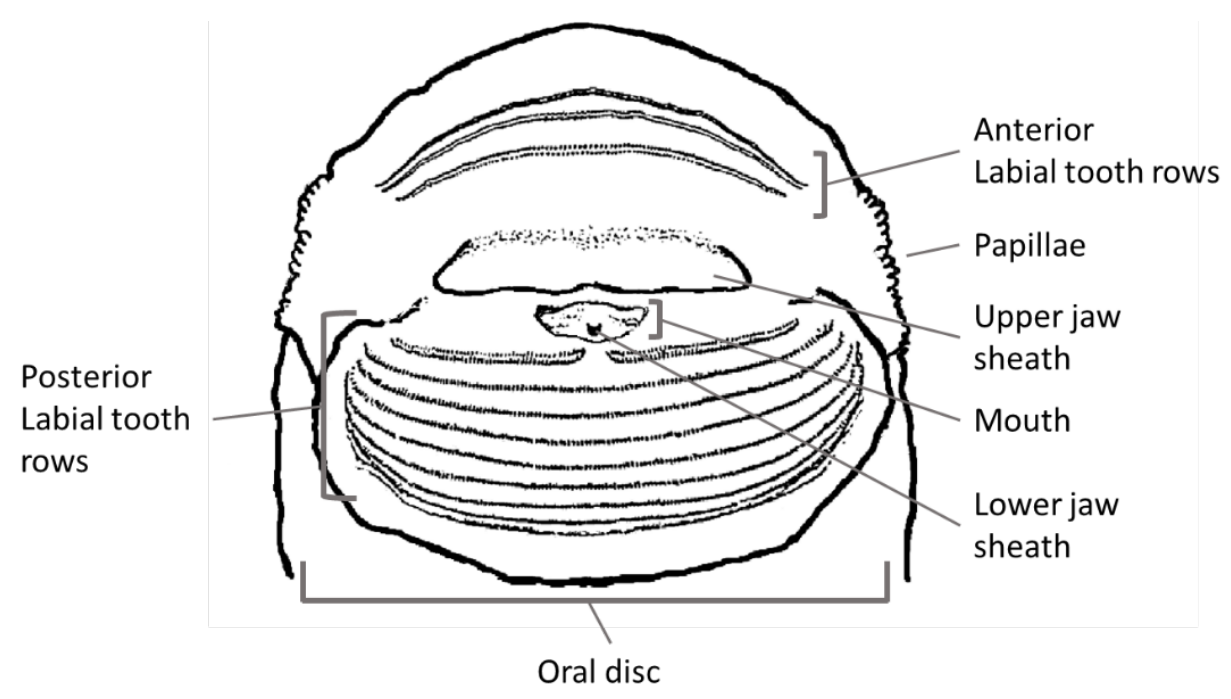

Figure 1. Stylized outline of an Ascaphus truei tadpole identifying aspects of oral morphology. 
bioRxiv preprint doi: https://doi.org/10.1101/2020.04 06 .027664 this version posted January 27,2021 . The copyright holder for this preprint (which was not certified by peer review) is the author/funder, who has granted bioRxiv a license to display the preprint in perpetuity. It is made available under aCC-BY-NC-ND 4.0 International license.
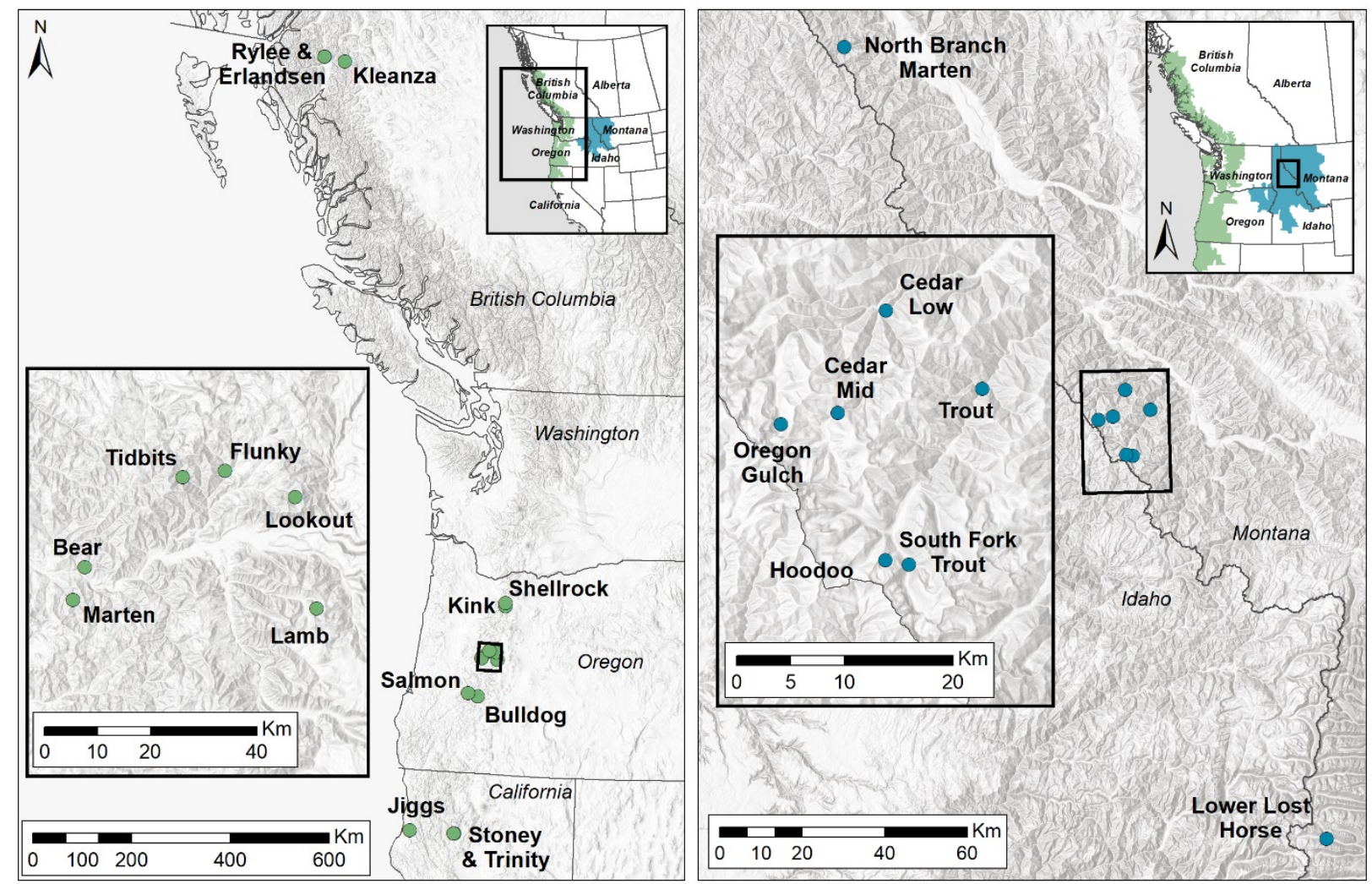

Figure 2. Sampling locations for Ascaphus truei (left) and Ascaphus montanus (right). Inset maps show estimated range boundaries for $A$. truei (in green) and $A$. montanus (in blue). Range maps from NatureServe \& IUCN (2012). 


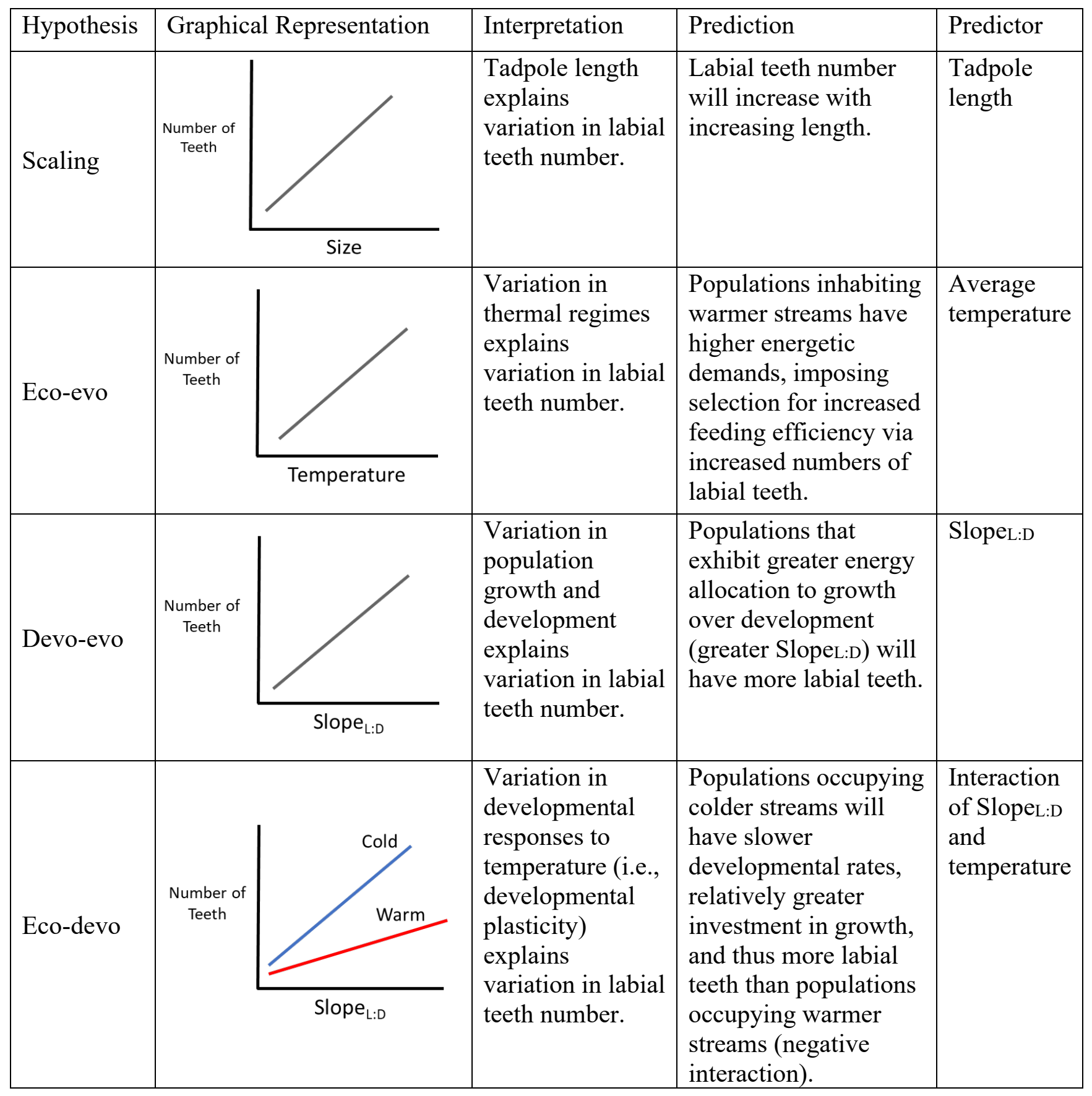

Figure 3. Overview of our predictions for the scaling hypothesis and our three eco-evo-devo hypotheses. See text for detailed explanation. 


\section{MATERIALS AND METHODS}

\section{Tadpole collection}

We sampled stream reaches ( $\sim 100 \mathrm{~m}$ in length) in the summers of 2016 and 2017 across British Columbia $(\mathrm{N}=3)$, Oregon $(\mathrm{N}=10)$, California $\mathrm{N}=3$ ), and Montana $(\mathrm{N}=8$; Figure 2; site coordinates available in Table $\mathrm{S} 1$ ). We captured tadpoles by shifting and brushing rocks and benthic substrate while holding an aquarium net downstream. Tadpoles were held in thermoses in the field, and were later euthanized, photographed laterally on a grid, fixed in formalin, and stored in $95 \%$ ethanol. All tadpole collection and euthanasia was performed under the following permits: California Department of Fish and Wildlife permit number SC-12131; Oregon Department of Fish and Wildlife permit numbers 117-16 and 110-17; Montana Department of Fish, Wildlife, and Parks permit numbers 2016-100 and 2017-060; Simon Fraser University Animal Care Committee protocol 1130B-14; and Institutional Animal Care and Use Committee protocol 16-6667AA.

\section{Labial teeth data collection}

We selected ten specimens from each site for a total of 240 individuals (160 A. truei and $80 \mathrm{~A}$. montanus). We selected specimens that were large enough to pin and photograph without destroying the specimen (Gosner stage $>28$; Gosner, 1960), and for which the developmental stage was not so advanced that the suctorial mouth was reduced (Gosner stage $<41$ ). Specimens were pinned with the mouth open to show a full view of the labial teeth rows. We took at least three photographs of each specimen using an Olympus SZX10 scope: full view of mouth, anterior rows only, and posterior rows only (Figure S1).

For each specimen, we first calculated the labial tooth row formula (LTRF), designated as the number of rows in the anterior labium (A) / the number of rows in the posterior labium (P). Anterior and posterior rows were numbered from anterior to posterior within the labium (Altig and McDiarmid, 1999). The most posterior row was defined as requiring distinct, discernible teeth throughout the row. If upon zooming in on a row, no distinct teeth were discernible, the row was not included in the LTRF. A and P values were followed by a row number in parentheses if a medial gap was present in the row. For example, a tadpole with 3 anterior rows and 7 posterior rows would have an LTRF of 3/7. If the first posterior row of teeth had a medial gap, then the LTRF would be 3/7(1). Rows consisting of two sub-rows on each tooth ridge were recorded as biserial and referred to as anterior or posterior.

We then used Adobe Photoshop and ImageJ (Rasband, 2018) to count individual teeth in the following rows: A3 anterior, A3 posterior, P1 posterior, P2, and P3. In specimens where the $\mathrm{P} 2$ row was biserial, we counted the $\mathrm{P} 2$ posterior row. These five rows were selected because their ends were consistently discernible from the center to the outer edges of the oral disc. Each tooth was individually marked with a red dot in ImageJ and counted moving from left to right. The same count was then performed with a dot of a different color moving from right to left. If the two counts matched, the number of teeth was recorded for the row. If the two counts were not the same, a third count was performed to serve as a tiebreaker. In a small number of cases, counts were initially listed as "NA" for one of the following reasons: a photograph was too blurry for all teeth to be discernible, there were teeth missing, there was damage to the tooth row, or the view of the teeth was obstructed. In these cases, we filled in NA values using one or more of the following approaches: (1) we used ImageJ to sharpen blurry edges to improve count 
accuracy; (2) we re-photographed the specimen; and/or (3) we estimated tooth counts based on the spacing in the rest of the row in areas of glare or missing teeth.

We counted individual teeth in all five rows for 114 individuals. Correlations among row counts were then used to reduce the number of rows counted to three (A3 anterior, A3 posterior, and P2) for the remainder of the specimens, as counts for these rows were not as highly correlated (see Results). Counts of these three rows from all 240 specimens were used in all subsequent analyses.

\section{Staging and length measurements}

Each tadpole was assigned a developmental stage based on a (modified) staging system developed by Gosner (1960). The unique and slow development of Ascaphus tadpoles (Brown, 1990; Brown, 1975) required that we modify the original Gosner staging system, accommodating distinctive developmental features in Ascaphus, such as the late reduction of the suctorial disc and oral labia (manuscript authors, unpublished data). We used ImageJ to measure the length of each tadpole (tip of snout to tip of tail) from the lateral photographs; each tadpole was measured twice, and the values were averaged.

\section{Temperature predictor variables}

Annual temperatures were calculated from continuous temperature loggers (Onset Hobo Pendants UA-001-064) installed at each site. Data loggers were installed at the upstream and downstream ends of the stream reach using rebar pounded into the substrate. Data loggers were protected from debris and sunlight using PVC housing drilled with holes to allow water flow. Temperature was recorded every 4 hours. Annual temperature for most sites was calculated on either a 2016-2017 or 2017-2018 water year (October 1 - September 30), although some sites used a different time frame or were missing small amounts of data (see Table S1 for dates and loggers used in calculations for each site).

\section{Analyses}

All analyses were performed using R v. 3.5.3 (R Core Team, 2019). We first determined if we could treat Gosner stage as continuous in our models, rather than as an ordered factor. For each of the three labial tooth rows, we ran two GLMs treating Gosner stage as either a continuous or ordinal variable. For these and all subsequent GLM models, we checked the goodness of fit of the GLM with a Poisson error distribution using a chi-square test based on the residual deviance and degrees of freedom. If the Poisson distribution did not fit the data, we used a negative binomial distribution fit with the $\mathrm{R}$ package $M A S S$ (Venables and Ripley, 2002). We then compared the models using a likelihood ratio test, AIC, and BIC. We ran this analysis separately for each species on each labial tooth row.

To estimate the relative investment in growth versus development in each population, we calculated slope coefficients of the relationships between length and developmental stage. The slope coefficients estimated with the labial tooth number dataset $(\mathrm{N}=240)$ had large slope variances and slope standard errors. Therefore, to bolster our population estimates, we used a larger dataset ( $\mathrm{N}=814$, manuscript authors, unpublished data.) to calculate slope estimates for each population. This dataset contained length and Gosner stage data for each population (see Table S2 for population sample sizes), with Gosner stage not exceeding 40. For both species, the means of the slopes from each dataset were not different; however, the estimates from the larger dataset had significantly lower slope variances and slope standard errors (Table S3). We 
therefore used estimates from the larger dataset in the following analyses and results. These estimates are subsequently referred to as Slope L:D.

We used descriptive statistics to describe patterns in LTRF and tooth number variation. We tested for species differences in labial tooth counts using a GLM with a Poisson or negative binomial distribution (based on goodness of fit tests) for each tooth row. We also tested for population differences in labial tooth counts using an ANOVA for each tooth row. We tested our hypotheses using species- and tooth row-specific GLMs and calculated a pseudo- ${ }^{2}$ for each model (Zuur et al., 2009). We tested for correlations among predictors prior to running the models. Our predictor variables_-length, Slope L/D, average temperature, and the interaction between average temperature and slope estimate - each test the prediction of a specific a hypothesis (see Figure 3). Plots were made using the packages ggplot2 (Wickham, 2016) and jtools (Long, 2020).

\section{RESULTS}

Based on correlations in counts across the five rows of 114 individuals, we reduced the number of rows counted to A3 anterior, A3 posterior, and P2 for the remainder of the specimens. Rows P1 and P3 were dropped since they were highly correlated with P2 ( $\mathrm{r}>0.95$ in both cases). $\mathrm{P} 2$ was retained over P1 because it was not biserial; P2 was retained over P3 because the P2 row photo quality was generally higher than P3 (e.g. depth of field was superior/least blurry at the edges of the oral disc).

\section{Gosner stage analyses}

In both species, a Poisson GLM fit the A3 anterior and P2 data, while a negative binomial GLM was the best fit for the A3 posterior data. For the A3 anterior data, treating Gosner stage as a continuous variable was the better model according to AIC and BIC, with the likelihood ratio test showing no significant difference between the models. For the A3 posterior row, treating Gosner stage as a continuous variable was the better model according to BIC, with strong support for both models based on AIC. The likelihood ratio tests for A3 posterior showed a significant difference between the models for both A. truei $(p=0.01)$ and A. montanus $(p=$ 0.04). In both species, the P2 data had the least support for a continuous treatment, with BICs in support of continuous treatment, but AIC and likelihood ratio tests with little to no support (full results in Table S4). Given these mixed results, we chose to treat Gosner stage as continuous for the remainder of analyses to simplify model fitting and interpretation.

\section{Patterns of labial teeth variation}

All specimens had identical LTRF values for the number of anterior rows (3) but varied in the number of posterior rows (7-9). All specimens had a medial gap in the P1 row and were biserial in rows A2, A3, and P1. All 30 individuals from the three British Columbia sites also had a biserial P2 row (Table S5), which was not observed in other specimens.

Using GLMs with a negative binomial distribution for all three tooth rows, we found that A. truei had higher tooth counts in every row (Table S6). We also found that populations varied in their labial tooth counts for all three rows in both A. montanus (Figure S2; A3-anterior: ANOVA $\mathrm{F}_{(7,72)}=16.32, \mathrm{p}<0.0001$; A3-posterior: ANOVA $\left(\mathrm{F}_{(7,72)}=14.7, \mathrm{p}<0.0001\right)$; $\mathrm{P} 2$ : ANOVA $\left.\left(\mathrm{F}_{(7,72)}=27.39, \mathrm{p}<0.0001\right)\right)$ and A truei (Figure S3; A3-anterior: ANOVA $\mathrm{F}_{(15,144)}=9.16$, $\mathrm{p}<0.0001$; A3-posterior: ANOVA $\left(\mathrm{F}_{(14,144)}=6.00, \mathrm{p}<0.0001\right)$; $\mathrm{P} 2$ : $\operatorname{ANOVA}\left(\mathrm{F}_{(15,144)}=12.60\right.$, $\mathrm{p}<0.0001)$ ). 


\section{Testing drivers of labial tooth number variation}

The predictors for our scaling and eco-evo-devo hypotheses were not highly correlated (all $|\mathrm{r}|<0.59$, Table S7), so were all included as predictors in our GLMs. We found similar drivers of labial tooth count variation among tooth rows within each species of tailed frogs and between the two species. Within A. montanus, we found support for positive relationships for all four predictors within each of the three labial tooth rows (Figure 4). These models explained $66 \%$ of variation in the A3 anterior row, $64 \%$ of the variation in the A3 Posterior row, and $81 \%$ of the variation in the $\mathrm{P} 2$ row. Within $A$. truei, we found consistent, positive support for the scaling hypothesis (Figure 4). We also found support for a positive relationship between temperature and tooth counts in all three tooth rows. Within the A3 Anterior tooth row, we also found a negative relationship with the interaction between temperature and population slope estimate. Within the P2 tooth row, we also found a significant, negative relationship with the population slope estimates. See Table S8 for full results from the GLMs. 


\section{A. montanus}

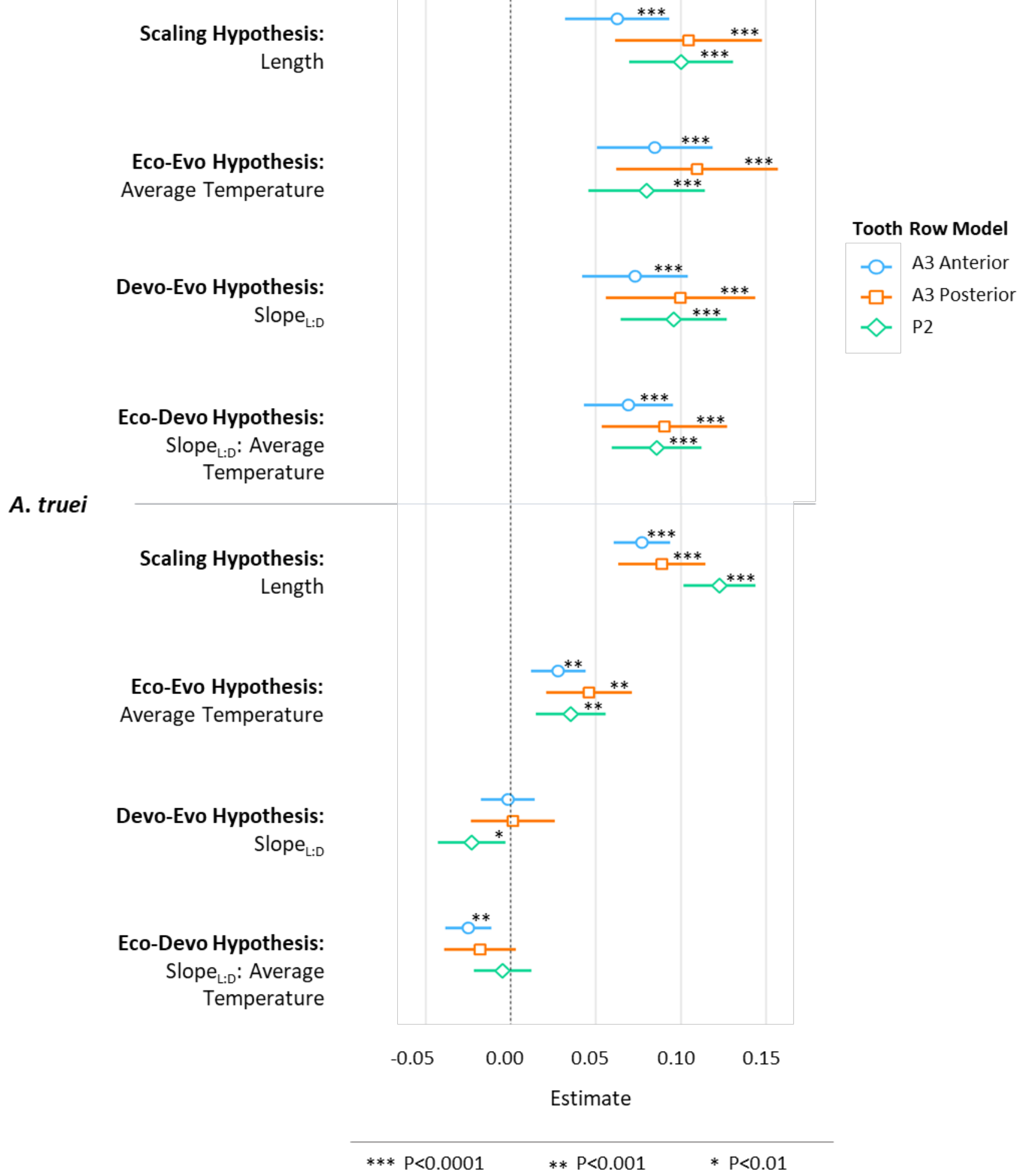

Figure 4. Results from the GLMs investigating our eco-evo-devo hypotheses for each tooth row. Bars on the coefficient estimates are $95 \%$ confidence intervals. 


\section{DISCUSSION}

Understanding the evolution of traits is an enduring and influential research theme in ecology (Knott et al., 2019). The need for interdisciplinary and multi-scale approaches to uncover complex ecological interactions (Thompson et al., 2001; Reiners et al., 2017; McCallen et al., 2019) has led to the development of integrative frameworks that can help account for interacting intrinsic and extrinsic drivers of phenotypic variation (e.g., Sultan, 2007; Sanger and Rajakumar, 2019; Skúlason et al., 2019; Wilsterman et al., 2020). In this study, we used a framework combining approaches from ecology, evolution, and development (eco-evo-devo framework; Skúlason et al., 2019) to uncover drivers of labial tooth number variation in two species of tailed frog, Ascaphus montanus and A. truei. Using this approach, we explained 64$81 \%$ of the variation in labial tooth number in three labial tooth rows for $A$. montanus and 37 $54 \%$ of the variation in labial tooth number in the same tooth rows for $A$. truei. We identified drivers that represent complex interactions between the organism and environment, which may have been missed if only a single axis of causation was investigated. For example, if we had considered only the direct effect of temperature on labial tooth number variation (only an ecoevo perspective), we would have explained a maximum of $23 \%$ of the variation in labial tooth number for any of the tooth rows in both species (Table S9). Our results therefore highlight the advantages of using an integrative framework to understand trait evolution.

\section{Drivers of labial tooth number variation}

We found consistent support for our scaling hypothesis in both species and all tooth rows, demonstrating that the number of labial teeth per tooth row increased with tadpole length. We expected this result, as tadpoles experiencing allometric growth would have larger mouths at larger body sizes, which could support more teeth. A study by Vences et al. (2002) supports our observed relationship, though indirectly. These authors found that the number of labial teeth in one anterior tooth row increased with water volume, which was positively correlated with tadpole snout-vent length. Similarly, Conradie and Conradie (2015) found positive relationships between tadpole length and the number of posterior labial tooth rows in four species of ghost frogs (family: Heleophrynidae), demonstrating an increase in number of overall labial teeth with body size. In our study, even after accounting for this significant effect of tadpole length, the environmental and developmental variables investigated through our eco-evo-devo hypotheses remained significant drivers of variation in labial tooth number.

We found unanimous support for our eco-evo hypothesis that the energetic demands of occupying warmer streams may favor increased labial teeth number to improve feeding efficiency. Although this relationship has not been investigated in other systems, there is supporting evidence to suggest that increased number of labial teeth may be an evolved response to warm temperatures. De Sousa et al. (2015) found that tadpoles feeding in warm temperatures had faster gape cycles and a smaller maximum gape, suggesting a tradeoff between feeding speed and surface area fed upon. Additionally, Venesky et al. (2010) investigated the effects of missing labial teeth on tadpole feeding kinematics and found that tadpoles with fewer labial teeth compensated for decreased feeding efficiency by increasing gape cycles. These two studies demonstrate that both increased temperatures and decreased labial tooth numbers may reduce food consumption without compensatory responses. Thus, maximizing the amount of food consumed in quick gape cycles may be particularly important in warm streams to maintain a large enough energy budget to support development and growth. Similarly, increased numbers of labial teeth may be evolved responses to increase feeding efficiency in warmer temperatures. 
The results from our models also support variation in population developmental processes influencing labial tooth number (evo-devo hypothesis). Using population slope estimates representing the relationship between tadpole length and developmental stage (Slope $\mathrm{L}: \mathrm{D})$, we found support for this hypothesis in all tooth rows in A. montanus and in the $\mathrm{P} 2$ row in A. truei. Our Slope L:D metric was used as a proxy for population developmental processes, specifically energy allocation strategies. Therefore, we expected populations with higher Slope L:D values to reflect greater energy allocation towards growth over development and have a greater number of labial teeth. The relationships in $A$. montanus were positive and in concordance with our prediction, while the significant relationship in $A$. truei was not. Indeed, the relationship between size and developmental stage only represents one aspect of development. Changes in the sequence, rate, or timing of developmental events can lead to phenotypic variation (Chipman et al., 2000; Chipman, 2002), including in oral morphology (Vera Candioti et al., 2011; Grosso et al., 2019). Differences in developmental trajectories due to these proximate mechanisms may be contributing to the variation observed in this study or explain the opposing relationships between labial teeth number and our developmental proxy. Nevertheless, for $A$. montanus, the effects of variation in population developmental processes on labial tooth number variation are clear.

Growth and development in tadpoles are plastic and can be influenced by environmental variables such as temperature (Newman, 1992; Denver et al., 1998; Ruthsatz et al., 2018). Our results support temperature as a cue for developmental plasticity resulting in variation in labial teeth number (eco-devo hypothesis). We found one negative relationship in A. truei (A3 Anterior row) such that the number of labial teeth increases with Slopel:D in colder streams, corroborating our prediction. Warm temperatures may prompt a shift in energy allocation towards development rather than growth as high temperatures are associated with increased metabolic demand and rates of development (Gillooly et al., 2001 \& 2002; Angilletta and Dunham, 2003; Angilletta et al., 2004; Brown et al., 2004; Gomez-Mestre et al., 2010; Liess et al., 2013). This relationship is also consistent with the temperature-size rule that warmer temperatures lead to smaller-bodied ectotherms (Angilletta and Dunham, 2003; Walters and Hassall, 2006). Results from experiments by Vences et al. (2002) support this finding as they found that tadpoles developing in warmer ponds had fewer labial teeth overall. In contrast, we found positive relationships for the eco-devo hypothesis in all $A$. montanus tooth rows, demonstrating that the number of labial teeth increased with Slopel:D in warmer streams more than in colder streams. These relationships were not expected but could be explained by a compensatory plastic response or differences in energy budget. As with our eco-evo hypothesis, increased number of labial teeth may be critical for energy acquisition, thus a shift to labial tooth proliferation in metabolically demanding warm streams may explain our observations. Unlike the eco-evo hypothesis, this shift would be a plastic response. Alternatively, A. montanus may not be energy-limited and be able to maintain growth and development equally. In warm streams, increased metabolism may allow for faster growth rates and thus lead to more labial teeth than in cold streams. Evidently, further studies are needed to understand the relationship between temperature and development and its effect on morphology in A. montanus.

\section{Broad patterns in labial tooth variation}

Our study uncovered patterns in labial tooth row and number variation within and between species of tailed frogs. Despite the broad geographic sampling across the two species, the labial tooth row formula (LTRF) was relatively consistent, with variation only in the number 
of posterior rows. This variation is likely due to developmental stage and size, as has been shown in other species (Bresler and Bragg, 1954; Conradie and Conradie, 2015). Interestingly, all 30 tadpoles from British Columbia had a biserial P2 row, which was not found in any of the other 210 Ascaphus individuals. Bifurcation of the tooth row may be related to increased flexibility (Annibale et al., 2020), suggesting a possible functional role, and/or differences in developmental sequences (Altig and McDiarmid, 2001; Vera Candioti et al., 2011; Grosso et al., 2019). Further investigation is needed to determine the geographic extent and underlying cause of the unique $\mathrm{P} 2$ bifurcation.

We also found that $A$. truei had more teeth than $A$. montanus in all three labial tooth rows. These species differences in overall tooth counts may reflect evolutionary history, the outcome of neutral processes since divergence, or ecological differences. Ascaphus truei and A. montanus diverged from their common ancestor over 5 million years ago, following the rise of the Cascade Mountain range in North America and associated climatic changes (Nielson et al., 2001). Despite both occupying montane streams, these species experience different environmental conditions that reflect their coastal (A. truei) and continental (A. montanus) climate regimes. From the sites we sampled, we found that $A$. truei streams had higher average temperatures than $A$. montanus, as well as greater variation in average temperature. As temperature was a positive driver of tooth variation in all tooth rows for both species, higher average temperatures in A. truei may explain why this species has more teeth overall. However, this study did not seek to understand trait divergence between the species and further investigation into the influences of ecological differences and evolutionary history is needed.

\section{Conclusions}

Although tadpole oral morphology has played an important role in clarifying relationships among diverse species of frogs (Altig, 2006; Vera Candioti and Altig, 2010), this is one of few studies investigating intraspecific diversity in tadpole oral morphology and the mechanisms that maintain it. By operationalizing an eco-evo-devo framework (Skúlason et al., 2019), we uncovered interconnected relationships between temperature and development driving labial tooth number variation among populations and species of tailed frogs. These drivers were found to influence labial tooth number variation both directly and indirectly through interactions. Interrelated and complex drivers are often found in other studies investigating anuran morphology (e.g., Ledón-Retting and Pfennig, 2011; Womack and Bell, 2020). This study highlights the increased power to explain variation in morphological traits as well as uncover unexpected patterns and observations by using an integrative framework. As ecological research is trending towards the use of large datasets (McCallum, 2019), employing integrative methods will be key to fully understanding phenotypic variation and evolution. 


\section{REFERENCES}

Altig, R., and R. McDiarmid. 1999. Body plan: development and morphology, p. 24-51. In: Tadpoles: The biology of anuran larvae. R. McDiarmid and R. Altig (eds.). University of Chicago Press, Chicago.

Altig, R. 2006. Discussions of the origin and evolution of the oral apparatus of anuran tadpoles. Acta Herpetologica 1:95-105. https://https://doi.org/10.13128/Acta_Herpetol-1292.

Altig, R., and G. F. Johnston. 1989. Guilds of anuran larvae: relationships among developmental modes, morphologies, and habitats. Herpetological Monographs 3:81-109. https://doi.org/10.2307/1466987.

Angilletta Jr., M. J., and A. E. Dunham. 2003. The temperature-size rule in ectotherms: simple evolutionary explanations may not be general. The American Naturalist 162:332-342. https://doi.org/10.1086/377187.

Angilletta, M. J., T. D. Steury, and M. W. Sears. 2004. Temperature, growth rate, and body size in ectotherms: Fitting pieces of a life-history puzzle. Integrative and Comparative Biology 44:498-509. https://doi.org/10.1093/icb/44.6.498.

Annibale, F. S., V. T. T. De Sousa, C. E. De Sousa, M. D. Venesky, D. De Cerqueira RossaFeres, F. Nomura, and R. J. Wassersug. 2019. Influence of substrate orientation on tadpoles' feeding efficiency. Biology Open 8:bio037598. DOI: 10.1242/bio.037598.

Annibale, F. S., V. T. T. De Sousa, C. E. De Sousa, M. D. Venesky, D. de C. Rossa-Feres, R. J. Wassersug, and F. Nomura. 2020. Smooth, striated, or rough: how substrate textures affect the feeding performance of tadpoles with different oral morphologies. Zoomorphology 139:97-110. https://doi.org/10.1007/s00435-019-00469-x.

Arendt, J. D. 2006. The cellular basis for phenotypic plasticity of body size in Western Spadefoot toad (Spea hammondi) tadpoles: Patterns of cell growth and recruitment in response to food and temperature manipulations. Biological Journal of the Linnean Society 88:499-510. https://doi.org/10.1111/j.1095-8312.2006.00642.x.

Bresler, J., and A. N. Bragg. 1954. Variations in the rows of labial teeth in tadpoles. Copeia 1954:255-257. https://doi.org/10.2307/1440035.

Brown, H. A. 1975. Temperature and development of the tailed frog, Ascaphus truei. Comparative Biochemistry and Physiology - Part A: Physiology 50A:397-405. https://doi.org/10.1016/0300-9629(75)90033-X.

Brown, H. A. 1989. Developmental anatomy of the tailed frog (Ascaphus truei): a primitive frog with large eggs and slow development. Journal of Zoology 217:525-537. https://doi.org/10.1111/J.1469-7998.1989.TB02509.X.

Brown, H. A. 1990. Morphological variation and age-class determination in overwintering tadpoles of the tailed frog, Ascaphus truei. Journal of Zoology 220:171-184. https://doi.org/10.1111/J.1469-7998.1990.TB04301.X.

Brown, J. H., J.F. Gillooly, A.P. Allen, V.M. Savage, and G.B. West. 2004. Toward a metabolic theory of ecology. Ecology 85:1771-1789. https://doi.org/10.1016/B978-0-12-8146125.00011-7.

Bury, R. B., and M. J. Adams. 1999. Variation in age at metamorphosis across a latitudinal gradient for the tailed frog, Ascaphus truei. Herpetologica 55:283-291.

Chipman, A. D. 2002. Variation, plasticity and modularity in anuran development. Zoology 105:97-104. https://doi.org/10.1078/0944-2006-00054.

Chipman, A. D., A. Haas, E. Tchernov, and O. Khaner. 2000. Variation in anuran embryogenesis: differences in sequence and timing of early developmental events. 
Journal of Experimental Zoology 288:352-365. https://doi.org/10.1002/1097010X(20001215)288:4<352::AID-JEZ8>3.0.CO;2-2.

Conradie, W., and C. Conradie. 2015. Correlation between development and increase of number of labial tooth rows in Ghost Frog tadpoles (Anura: Heleophrynidae). Acta Herpetologica 13:13-19. https://doi.org/10.13128/Acta.

Coyne, J.A., and H.A. Orr. 2004. Speciation. Sinauer Associates, Sunderland, Massachusetts.

De Sousa, V. T. T., F. Nomura, D. de C. Rossa-Feres, G. V. Andrade, T. L. Pezzuti, R. J. Wassersug, and M. D. Venesky. 2015. Differential effects of temperature on the feeding kinematics of the tadpoles of two sympatric anuran species. Journal of Experimental Zoology Part A: Ecological Genetics and Physiology 323:456-465. https://doi.org/10.1002/jez.1941.

Denver, R. J., N. Mirhadi, and M. Phillips. 1998. Adaptive plasticity in amphibian metamorphosis: Response of Scaphiopus hammondii tadpoles to habitat desiccation. Ecology 79:1859-1872. https://doi.org/10.1890/00129658(1998)079[1859:apiamr]2.0.co;2.

Gilbert, S. F., T. C. G. Bosch, and C. Ledón-Rettig. 2015. Eco-Evo-Devo: developmental symbiosis and developmental plasticity as evolutionary agents. Nature Reviews Genetics 16:611-622. https://doi.org/10.1038/nrg3982.

Gillooly, J. F., J. H. Brown, G. B. West, V. M. Savage, and E. L. Charnov. 2001. Effects of size and temperature on metabolic rate. Science 293:2248-2251. https://doi.org/10.1126/science.1061967.

Gillooly, J. F., E. L. Charnov, G. B. West, V. M. Savage, and J. H. Brown. 2002. Effects of size and temperature on developmental time. Nature 417:70-73. https://doi.org/10.1038/417070a.

Gomez-Mestre, I., V. L. Saccoccio, T. Iijima, E. M. Collins, G. G. Rosenthal, and K. M. Warkentin. 2010. The shape of things to come: linking developmental plasticity to postmetamorphic morphology in anurans. Journal of Evolutionary Biology 23:1364-1373. https://doi.org/10.1111/j.1420-9101.2010.02016.x.

Gosner, K. L. 1960. A simplified table for staging anuran embryos and larvae with notes on identification. Source: Herpetologica 16:183-190.

Govaert, L., E. A. Fronhofer, S. Lion, C. Eizaguirre, D. Bonte, M. Egas, A. P. Hendry, A. De Brito Martins, C. J. Melián, J. A. M. Raeymaekers, I. I. Ratikainen, B. E. Saether, J. A. Schweitzer, and B. Matthews. 2019. Eco-evolutionary feedbacks-Theoretical models and perspectives. Functional Ecology 33:13-30. https://doi.org/10.1111/13652435.13241.

Gradwell, N. 1971. Ascaphus tadpole: experiments on the suction and gill irrigation mechanisms. Canadian Journal of Zoology 49:307-332. https://doi.org/10.1139/z71-047.

Grosso, J., D. Baldo, D. Cardozo, F. Kolenc, C. Borteiro, M. I. R. de Oliveira, M. F. Bonino, D. A. Barrasso, and F. V. Candioti. 2019. Early ontogeny and sequence heterochronies in Leiuperinae frogs (Anura: Leptodactylidae). PLoS ONE 14: e0218733. https://doi.org/10.1371/journal.pone.0218733.

Hayes, M.P., and T. Quinn (editors). 2015. Review and synthesis of the literature on tailed frogs (genus Ascaphus) with special reference to managed landscapes. Cooperative Monitoring Evaluation and Research Report CMER 01-107. Washington State Forest Practices Adaptive Management Program. Washington Department of Natural Resources, Olympia, WA. 
Houle, D., D. R. Govindaraju, and S. Omholt. 2010. Phenomics: The next challenge. Nature Reviews Genetics 11:855-866. https://doi.org/10.1038/nrg2897.

Knott, J., E. LaRue, S. Ward, E. McCallen, K. Ordonez, F. Wagner, I. Jo, J. Elliott, and S. Fei. 2019. A roadmap for exploring the thematic content of ecology journals. Ecosphere 10: e02801. https://doi.org/10.1002/ecs2.2801.

Ledón-Rettig, C. C., and D. W. Pfennig. 2011. Emerging model systems in eco-evo-devo: the environmentally responsive spadefoot toad. Evolution and Development 13:391-400. https://doi.org/10.1111/j.1525-142X.2011.00494.x.

Liess, A., O. Rowe, J. Guo, G. Thomsson, and M. I. Lind. 2013. Hot tadpoles from cold environments need more nutrients life history and stoichiometry reflects latitudinal adaptation. Journal of Animal Ecology 82:1316-1325. https://doi.org/10.1111/13652656.12107.

Long, J. A. 2020. jtools: Analysis and presentation of social scientific data. R package version 2.1.0, <URL: https://cran.r-project.org/package=jtools $>$.

McCallen, E., J. Knott, G. Nunez-Mir, B. Taylor, I. Jo, and S. Fei. 2019. Trends in ecology: shifts in ecological research themes over the past four decades. Frontiers in Ecology and the Environment 17:109-116. https://doi.org/10.1002/fee.1993.

NatureServe, and IUCN. 2012. Ascaphus truei and Ascaphus montanus, 2008. In: IUCN Red List of Threatened Species. Version 2012.1. International Union for the Conservation of Nature (IUCN).

Newman, R. A. 1992. Adaptive plasticity in amphibian metamorphosis. BioScience 42:671-678. https://doi.org/10.2307/1312173.

Nielson, M., K. Lohman, and J. Sullivan. 2001. Phylogeography of the tailed frog (Ascaphus truei): implications for the biogeography of the Pacific Northwest. Evolution 55:147160. https://doi.org/10.1111/j.0014-3820.2001.tb01280.x.

Pigliucci, M. 2001. Phenotypic plasticity: beyond nature and nurture. Johns Hopkins University Press, Baltimore.

R Core Team. 2019. R: A language and environment for statistical computing. R Foundation for Statistical Computing, Vienna, Austria. https://www.R-project.org/.

Rasband, W. 2018. ImageJ v. 1.52a. U. S. National Institutes of Health, Bethesda, MD. https://imagej.nih.gov/ij/

Reiners, W. A., J. A. Lockwood, D. S. Reiners, and S. D. Prager. 2017. 100 Years of ecology: what are our concepts and are they useful? Ecological Monographs 87:260-277. https://doi.org/10.1002/ecm.1243.

Ruthsatz, K., M. A. Peck, K. H. Dausmann, N. M. Sabatino, and J. Glos. 2018. Patterns of temperature induced developmental plasticity in anuran larvae. Journal of Thermal Biology 74:123-132. https://doi.org/10.1016/j.jtherbio.2018.03.005.

Sanger, T. J., and R. Rajakumar. 2019. How a growing organismal perspective is adding new depth to integrative studies of morphological evolution. Biological Reviews 94:184-198. https://doi.org/10.1111/brv.12442.

Schwab, D. B., S. Casasa, and A. P. Moczek. 2019. On the reciprocally causal and constructive nature of developmental plasticity and robustness. Frontiers in Genetics 10:1-13. https://doi.org/10.3389/fgene.2018.00735.

Skúlason, S., K. J. Parsons, R. Svanbäck, K. Räsänen, M. M. Ferguson, C. E. Adams, P. A. Amundsen, P. Bartels, C. W. Bean, J. W. Boughman, G. Englund, J. Guðbrandsson, O. E. Hooker, A. G. Hudson, K. K. Kahilainen, R. Knudsen, B. K. Kristjánsson, C. A. L. 
Leblanc, Z. Jónsson, G. Öhlund, C. Smith, and S. S. Snorrason. 2019. A way forward with eco evo devo: an extended theory of resource polymorphism with postglacial fishes as model systems. Biological Reviews 94:1786-1808. https://doi.org/10.1111/brv.12534.

Sultan, S. E. 2007. Development in context: the timely emergence of eco-devo. Trends in Ecology \& Evolution 22. https://doi.org/10.1016/j.tree.2007.06.014.

Sultan, S.E. 2015. Organism \& Environment. Ecological Development, Niche Construction and Adaptation. Oxford University Press, New York.

Svensson, E. I. 2018. On reciprocal causation in the evolutionary process. Evolutionary Biology 45:1-14. https://doi.org/10.1007/s11692-017-9431-x.

Thompson, J. N., O. J. Reichman, P. J. Morin, G. A. Polis, M. E. Power, R. W. Sterner, C. A. Couch, L. Gough, R. Holt, D. U. Hooper, F. Keesing, C. R. Lovell, B. T. Milne, M. C. Molles, D. W. Roberts, and S. Y. Strauss. 2001. Frontiers of ecology. BioScience 51:1524. https://doi.org/10.1641/0006-3568(2001)051[0015:foe]2.0.co;2.

Venables, W., and B. Ripley. 2002. Modern Applied Statistics with S. 4th edition. Springer, New York.

Vences, M., M. Puente, S. Nieto, and D. R. Vieites. 2002. Phenotypic plasticity of anuran larvae: environmental variables influence body shape and oral morphology in Rana temporaria tadpoles. Journal of Zoology 257:155-162. https://doi.org/10.1017/S0952836902000754.

Venesky, M. D., D. C. Rossa-Feres, F. Nomura, G. V. De Andrade, T. L. Pezzuti, V. T. T. De Sousa, C. V. Anderson, and R. J. Wassersug. 2013. Comparative feeding kinematics of tropical hylid tadpoles. Journal of Experimental Biology 216:1928-1937. https://doi.org/10.1242/jeb.082040.

Venesky, M. D., R. J. Wassersug, and M. J. Parris. 2010. The impact of variation in labial tooth number on the feeding kinematics of tadpoles of southern leopard frog (Lithobates sphenocephalus). Copeia 2010:481-486. https://doi.org/10.1643/CG-09-093.

Vera Candioti, F., B. Haad, D. Baldo, F. Kolenc, C. Borteiro, and R. Altig. 2011. Different pathways are involved in the early development of the transient oral apparatus in anuran tadpoles (Anura: Leiuperidae). Biological Journal of the Linnean Society 104:330-345. https://doi.org/10.1111/j.1095-8312.2011.01727.x.

Vera Candioti, M. F., and R. Altig. 2010. A survey of shape variation in keratinized labial teeth of anuran larvae as related to phylogeny and ecology. Biological Journal of the Linnean Society 101:609-625. https://doi.org/10.1111/j.1095-8312.2010.01509.x.

Wallace, R. L., and L. V Diller. 1998. Length of the larval cycle of Ascaphus truei in coastal streams of the Redwood region, Northern California. Journal of Herpetology 32:404-409. https://doi.org/10.2307/1565455.

Walters, R.J., Hassall, M., 2006. The temperature-size rule in ectotherms: may a general explanation exist after all? The American Naturalist 167:510-523. https://doi.org/10.1086/501029.

Wassersug, R. J., and M. Yamashita. 2001. Plasticity and constraints on feeding kinematics in anuran larvae. Comparative Biochemistry and Physiology Part A 131:183-195. https://doi.org/10.1016/S1095-6433(01)00468-8.

Wickham, H. 2016. ggplot2: Elegant Graphics for Data Analysis. Springer-Verlag New York. Wilsterman, K., M. A. Ballinger, and C. M. Williams. 2020. A unifying, eco-physiological framework for animal dormancy. Functional Ecology:11-31. https://doi.org/10.1111/1365-2435.13718. 
Womack, M. C., and R. C. Bell. 2020. Two-hundred million years of anuran body-size evolution in relation to geography, ecology and life history. Journal of Evolutionary Biology:1-16. https://doi.org/10.1111/jeb.13679.

Zuur, A., E. Ieno, N. Walker, A. Saveliev, and G. Smith. 2009. Mixed Effects Models and Extensions in Ecology with R. Springer-Verlag, New York. 


\section{SUPPLEMENTAL MATERIAL}

Table S1. Temperature logger metadata.

\begin{tabular}{|c|c|c|c|c|c|c|c|}
\hline $\begin{array}{c}\text { State/ } \\
\text { Province }\end{array}$ & Site & $\begin{array}{l}\text { UTM } \\
\text { Zone }\end{array}$ & Easting & Northing & $\begin{array}{c}\text { Water } \\
\text { Year or } \\
\text { dates used } \\
\text { in } \\
\text { calculation }\end{array}$ & $\begin{array}{c}\text { Which } \\
\text { logger(s) } \\
\text { were used } \\
\text { for } \\
\text { calculation } \\
\text { of annual } \\
\text { temperature } \\
\end{array}$ & Notes \\
\hline$\overline{\mathrm{BC}}$ & Erlandsen & 9 & 516969 & 6050849 & $\begin{array}{l}08 / 29 / 2016 \\
- \\
08 / 25 / 2017\end{array}$ & upstream & \\
\hline $\mathrm{BC}$ & Rylee & 9 & 516437 & 6050850 & $N A$ & $N A$ & $\begin{array}{l}\text { No data } \\
\text { available - } \\
\text { used } \\
\text { Erlandson, } \\
\text { which is } \\
\text { adjacent } \\
\text { to Rylee }\end{array}$ \\
\hline$\overline{\mathrm{BC}}$ & Kleanza & 9 & 558620 & 6047977 & $\begin{array}{l}08 / 27 / 2016 \\
- \\
07 / 17 / 2017\end{array}$ & downstream & \\
\hline \multirow[t]{2}{*}{$\overline{\text { OR }}$} & \multirow[t]{2}{*}{ Bear } & 10 & 542151 & 4887252 & \multirow[t]{2}{*}{2016} & \multirow{2}{*}{$\begin{array}{l}\text { average of } \\
\text { upstream and } \\
\text { downstream }\end{array}$} & \\
\hline & & 10 & 542160 & 4887247 & & & \\
\hline$\overline{\mathrm{OR}}$ & Bulldog & 10 & 538628 & 4806332 & 2017 & $\begin{array}{l}\text { average of } \\
\text { upstream and } \\
\text { downstream }\end{array}$ & \\
\hline OR & Flunky & 10 & 561018 & 4900381 & 2017 & $\begin{array}{l}\text { average of } \\
\text { upstream and } \\
\text { downstream }\end{array}$ & \\
\hline OR & Kink & 10 & 581568 & 4991248 & 2017 & $\begin{array}{l}\text { average of } \\
\text { upstream and } \\
\text { downstream }\end{array}$ & \\
\hline$\overline{\text { OR }}$ & Lamb & 10 & 573566 & 4881933 & 2017 & upstream & \\
\hline \multirow[t]{2}{*}{$\overline{\mathrm{OR}}$} & \multirow[t]{2}{*}{ Lookout High } & 10 & 570504 & 4896876 & \multirow[t]{2}{*}{2017} & \multirow[t]{2}{*}{ upstream } & \\
\hline & & 10 & 570503 & 4896894 & & & \\
\hline \multirow[t]{2}{*}{$\overline{\mathrm{OR}}$} & \multirow[t]{2}{*}{ Marten } & 10 & 540750 & 4882750 & \multirow[t]{2}{*}{2016} & \multirow[t]{2}{*}{ upstream } & \\
\hline & & 10 & 540612 & 4882821 & & & \\
\hline$\overline{\mathrm{OR}}$ & Salmon & 10 & 519296 & 4811471 & 2017 & $\begin{array}{l}\text { average of } \\
\text { upstream and } \\
\text { downstream }\end{array}$ & \\
\hline
\end{tabular}




\begin{tabular}{|c|c|c|c|c|c|c|}
\hline OR & Shellrock & 10 & 581426 & 4997767 & 2017 & $\begin{array}{l}\text { average of } \\
\text { upstream and } \\
\text { downstream }\end{array}$ \\
\hline OR & Tidbits & 10 & 555356 & 4899411 & 2017 & downstream \\
\hline $\mathrm{CA}$ & Jiggs & 10 & 421297 & 4526710 & $\begin{array}{l}07 / 01 / 2016 \\
- \\
06 / 30 / 2017\end{array}$ & upstream \\
\hline $\mathrm{CA}$ & Stoney & 10 & 510299 & 4526853 & $\begin{array}{l}07 / 02 / 2016 \\
- \\
06 / 30 / 2017\end{array}$ & upstream \\
\hline $\mathrm{CA}$ & Trinity & 10 & 509917 & 4526895 & $\begin{array}{l}07 / 02 / 2016 \\
- \\
06 / 30 / 2017\end{array}$ & downstream \\
\hline MT & Cedar & 11 & 651786 & 5221161 & 2017 & upstream \\
\hline MT & CedarMid & 11 & 648921 & 5214668 & 2017 & upstream \\
\hline MT & Hoodoo & 11 & 650774 & 5205237 & 2017 & upstream \\
\hline MT & LowerLostHorse & 11 & 700701 & 5112392 & 2017 & downstream \\
\hline MT & NBranchMarten & 11 & 583653 & 5304212 & 2017 & upstream \\
\hline MT & OregonGulch & 11 & 645372 & 5213879 & 2017 & upstream \\
\hline MT & SFTrout & 11 & 653658 & 5205276 & 2017 & downstream \\
\hline MT & Trout & 11 & 657984 & 5216421 & $\begin{array}{l}08 / 07 / 2016 \\
- \\
07 / 30 / 2017\end{array}$ & downstream \\
\hline
\end{tabular}


Table S2. Population sample sizes of the extended dataset used for estimating slope coefficients of the relationships between size (length) and developmental stage (SlopeL:D).

\begin{tabular}{|l|l|r|}
\hline $\begin{array}{l}\text { State or } \\
\text { Province }\end{array}$ & Site & $\begin{array}{l}\text { Extended Dataset } \\
\text { Sample Size }\end{array}$ \\
\hline BC & Erlandsen & 10 \\
\hline BC & Rylee & 10 \\
\hline BC & Kleanza & 10 \\
\hline OR & Bear & 40 \\
\hline OR & Bulldog & 48 \\
\hline OR & Flunky & 36 \\
\hline OR & Kink & 23 \\
\hline OR & Lamb & 73 \\
\hline OR & Lookout High & 84 \\
\hline OR & Marten & 18 \\
\hline OR & Salmon & 29 \\
\hline OR & Shellrock & 67 \\
\hline OR & Tidbits & 54 \\
\hline CA & Jiggs & 25 \\
\hline CA & Stoney & 10 \\
\hline CA & Trinity & 32 \\
\hline MT & Cedar & 31 \\
\hline MT & CedarMid & 33 \\
\hline MT & Hoodoo & 34 \\
\hline MT & LowerLostHorse & 45 \\
\hline MT & NBranchMarten & 34 \\
\hline MT & OregonGulch & 10 \\
\hline MT & SFTrout & Trout \\
\hline MT & & 34 \\
\hline
\end{tabular}


Table S3. Labial tooth and extended dataset population Slope $\mathrm{L}: \mathrm{D}$ estimate statistics.

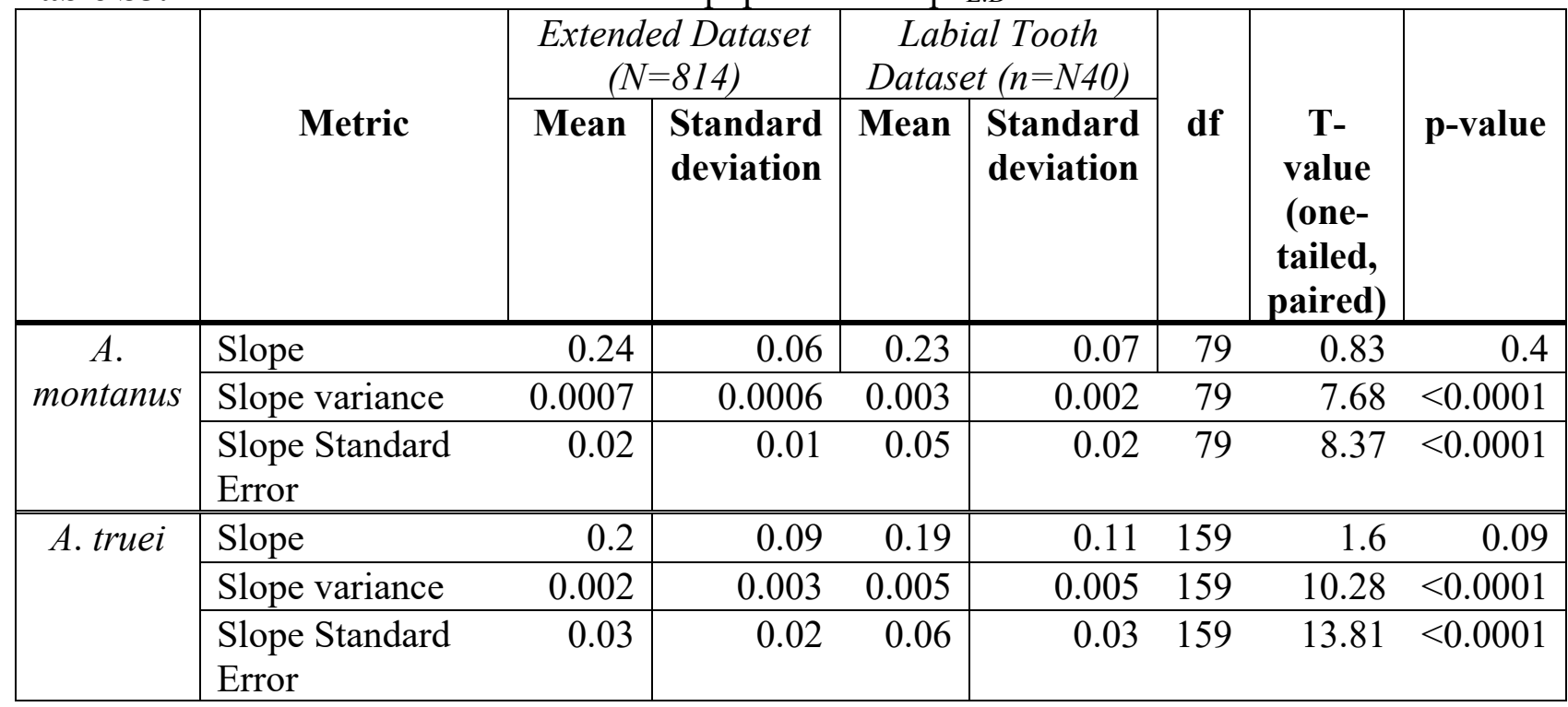


Table S4. AIC, BIC, and likelihood ratio test results for GLM models of tooth count by Gosner stage, fit as continuous and ordinal.

\begin{tabular}{|c|c|c|c|c|c|c|c|c|c|}
\hline Species & $\begin{array}{l}\text { Tooth } \\
\text { Row } \\
\end{array}$ & $\begin{array}{c}\text { Model } \\
\text { fit }\end{array}$ & $\begin{array}{c}\text { AIC } \\
\text { ordinal }\end{array}$ & $\begin{array}{c}\text { AIC } \\
\text { continuous }\end{array}$ & $\Delta \mathbf{A I C}$ & $\begin{array}{c}\text { BIC } \\
\text { ordinal }\end{array}$ & $\begin{array}{c}\text { BIC } \\
\text { continuous }\end{array}$ & $\Delta \mathrm{BIC}$ & $\begin{array}{l}\text { LR p- } \\
\text { value }\end{array}$ \\
\hline \multirow{3}{*}{$\begin{array}{c}\text { Ascaphus } \\
\text { truei }\end{array}$} & $\begin{array}{c}\mathrm{A} 3 \\
\text { anterior }\end{array}$ & poisson & 1183.6 & 1174.7 & 8.9 & 1220.5 & 1180.8 & 39.7 & 0.351 \\
\hline & $\begin{array}{c}\text { A3 } \\
\text { posterior }\end{array}$ & $\begin{array}{l}\text { negative } \\
\text { binomial }\end{array}$ & 1335.0 & 1337.2 & -2.2 & 1375.0 & 1346.4 & 28.6 & 0.014 \\
\hline & P2 & poisson & 1173.7 & 1199.4 & -25.7 & 1210.6 & 1205.6 & 5.0 & $<0.001$ \\
\hline \multirow{3}{*}{$\begin{array}{l}\text { Ascaphus } \\
\text { montanus }\end{array}$} & $\begin{array}{c}\mathrm{A} 3 \\
\text { anterior }\end{array}$ & poisson & 605.4 & 601.3 & 4.1 & 626.9 & 606.0 & 20.9 & 0.197 \\
\hline & $\begin{array}{c}\mathrm{A} 3 \\
\text { posterior }\end{array}$ & $\begin{array}{l}\text { negative } \\
\text { binomial }\end{array}$ & 676.8 & 677.6 & -0.8 & 700.6 & 684.7 & 15.9 & 0.039 \\
\hline & $\mathrm{P} 2$ & poisson & 603.9 & 608.5 & -4.6 & 625.3 & 613.3 & 12.0 & 0.009 \\
\hline
\end{tabular}


Table S5. LTRF and tooth counts for Ascaphus truei and A. montanus samples.

\begin{tabular}{|l|l|l|}
\hline & A. truei & A. montanus \\
\hline \multicolumn{1}{|c|}{ LTRF } & & \\
\hline $3 / 7(1)$ & 23 & 2 \\
\hline $3 / 8(1)$ & 101 & 33 \\
\hline $3 / 9(1)$ & 36 & 45 \\
\hline & & \\
\hline \multicolumn{1}{|c|}{ biserial rows } & & \\
\hline A2, A3, P1 & 130 & 80 \\
\hline A2, A3, P1, (P2) & 30 & 0 \\
\hline & & \\
\hline A3 anterior counts & & \\
\hline Min & 80 & 75 \\
\hline Median & 110 & 96 \\
\hline Mean & 110 & 99 \\
\hline Max & 141 & 141 \\
\hline & & \\
\hline A3 posterior counts & & \\
\hline Min & 63 & 67 \\
\hline Median & 115 & 98 \\
\hline Mean & 117 & 103 \\
\hline Max & 186 & 188 \\
\hline & & \\
\hline & & \\
\hline Min & 67 & 68 \\
\hline Median & 109 & 90 \\
\hline Mean & 109 & 97 \\
\hline Max & 156 & 136 \\
\hline & & \\
\hline \multicolumn{1}{|c|}{ Gosner Stage } & & \\
\hline Min & 28 & 30 \\
\hline Median & 34 & 34 \\
\hline Mean & 34 & 38 \\
\hline Max & & \\
\hline & & \\
\hline
\end{tabular}


Table S6. Results from GLM models testing for species differences in tooth number for each investigated tooth row.

\begin{tabular}{|c|c|c|c|c|c|c|c|}
\hline $\begin{array}{l}\text { Tooth } \\
\text { Row }\end{array}$ & Model fit & $\begin{array}{c}\text { Parameter ( } A \text {. } \\
\text { montanus as } \\
\text { reference factor } \\
\text { level) }\end{array}$ & $\begin{array}{c}\text { Fixed } \\
\text { effect } \\
\text { estimate }\end{array}$ & $\begin{array}{l}\text { Fixed } \\
\text { effect } \\
\text { std. } \\
\text { error }\end{array}$ & $\begin{array}{l}\text { Fixed } \\
\text { effect } z- \\
\text { value }\end{array}$ & $\begin{array}{l}\text { Fixed } \\
\text { effect p- } \\
\text { value }\end{array}$ & $\begin{array}{c}\text { Pseudo- } \\
\mathbf{R}^{2}\end{array}$ \\
\hline \multirow{2}{*}{$\begin{array}{c}\text { A3 } \\
\text { anterior }\end{array}$} & \multirow{2}{*}{$\begin{array}{l}\text { negative } \\
\text { binomial }\end{array}$} & Intercept & 4.592 & 0.016 & 285.91 & $<0.0001$ & \multirow{2}{*}{0.11} \\
\hline & & A. truei & 0.108 & 0.020 & 5.56 & $<0.0001$ & \\
\hline \multirow{2}{*}{$\begin{array}{c}\text { A3 } \\
\text { posterior }\end{array}$} & \multirow{2}{*}{$\begin{array}{l}\text { negative } \\
\text { binomial }\end{array}$} & Intercept & 4.638 & 0.023 & 203.09 & $<0.0001$ & \multirow{2}{*}{0.07} \\
\hline & & A. truei & 0.120 & 0.028 & 4.32 & $<0.0001$ & \\
\hline \multirow{2}{*}{$\mathrm{P} 2$} & \multirow{2}{*}{$\begin{array}{l}\text { negative } \\
\text { binomial }\end{array}$} & Intercept & 4.571 & 0.021 & 220.85 & $<0.0001$ & \multirow{2}{*}{0.08} \\
\hline & & A. truei & 0.116 & 0.025 & 4.60 & $<0.0001$ & \\
\hline
\end{tabular}


bioRxiv preprint doi: https://doi.org/10.1101/2020.04.06.027664; this version posted January 27, 2021. The copyright holder for this preprint (which was not certified by peer review) is the author/funder, who has granted bioRxiv a license to display the preprint in perpetuity. It is made available under aCC-BY-NC-ND 4.0 International license.

Table S7. Model predictor correlation matrix.

\begin{tabular}{|l|r|r|}
\hline A. montanus & \multicolumn{1}{|c|}{ Length } & SlopeL:D \\
\hline Length & & \\
\hline Slope L:D & 0.59 & \\
\hline Average Temperature & 0.52 & 0.26 \\
\hline \hline A. truei & & \\
\hline & Length & Slope $_{L: D}$ \\
\hline Length & & \\
\hline SlopeL:D & 0.18 & \\
\hline Average Temperature & 0.37 & 0.20 \\
\hline
\end{tabular}


Table S8. Results from the GLMs investigating our eco-evo-devo hypotheses for each tooth row.

\begin{tabular}{|c|c|c|c|c|c|}
\hline Species & $\begin{array}{c}\text { Tooth Row } \\
\text { (Distribution) }\end{array}$ & Parameter & $\begin{array}{c}\text { Coefficient } \\
\text { estimate } \\
\text { (std. error) } \\
\end{array}$ & $\begin{array}{c}\mathrm{z}- \\
\text { value }\end{array}$ & p-value \\
\hline \multirow{15}{*}{$\begin{array}{c}A . \\
\text { montanus }\end{array}$} & \multirow{5}{*}{$\begin{array}{l}\text { A3 anterior } \\
\text { (poisson) }\end{array}$} & Intercept & $4.567(0.012)$ & 380.46 & $<0.0001$ \\
\hline & & Length & $0.063(0.016)$ & 4.01 & $<0.0001$ \\
\hline & & Average Temperature & $0.085(0.017)$ & 4.89 & $<0.0001$ \\
\hline & & SlopeL:D & $0.073(0.016)$ & 4.63 & $<0.0001$ \\
\hline & & Slopel:D: Average Temperature & $0.069(0.013)$ & 5.18 & $<0.0001$ \\
\hline & \multirow{5}{*}{$\begin{array}{c}\text { A3 posterior } \\
\text { (negative } \\
\text { binomial) }\end{array}$} & Intercept & $4.597(0.017)$ & 276.02 & $<0.0001$ \\
\hline & & Length & $0.105(0.022)$ & 4.75 & $<0.0001$ \\
\hline & & Average Temperature & $0.110(0.024)$ & 4.52 & $<0.0001$ \\
\hline & & SlopeL:D & $0.100(0.022)$ & 4.46 & $<0.0001$ \\
\hline & & Slope L:D: Average Temperature & $0.091(0.019)$ & 4.82 & $<0.0001$ \\
\hline & \multirow{5}{*}{ P2 (poisson) } & Intercept & $4.535(0.012)$ & 370.98 & $<0.0001$ \\
\hline & & Length & $0.100(0.016)$ & 6.44 & $<0.0001$ \\
\hline & & Average Temperature & $0.080(0.017)$ & 4.59 & $<0.0001$ \\
\hline & & Slope $_{L: D}$ & $0.096(0.016)$ & 6.05 & $<0.0001$ \\
\hline & & Slopel:D: Average Temperature & $0.086(0.013)$ & 6.39 & $<0.0001$ \\
\hline \multirow{15}{*}{ A. truei } & \multirow{5}{*}{$\begin{array}{l}\text { A3 anterior } \\
\text { (poisson) }\end{array}$} & Intercept & $4.702(0.008)$ & 614.49 & $<0.0001$ \\
\hline & & Length & $0.077(0.008)$ & 9.11 & $<0.0001$ \\
\hline & & Average Temperature & $0.028(0.008)$ & 3.43 & 0.0006 \\
\hline & & SlopeL:D & $-0.002(0.008)$ & -0.20 & 0.8442 \\
\hline & & Slopet:D: Average Temperature & $-0.025(0.007)$ & -3.62 & 0.0003 \\
\hline & \multirow{5}{*}{$\begin{array}{c}\text { A3 posterior } \\
\text { (negative } \\
\text { binomial) }\end{array}$} & Intercept & $4.755(0.012)$ & 398.68 & $<0.0001$ \\
\hline & & Length & $0.089(0.013)$ & 6.78 & $<0.0001$ \\
\hline & & Average Temperature & $0.046(0.013)$ & 3.59 & 0.0003 \\
\hline & & Slope $\mathrm{L}: \mathrm{D}$ & $0.001(0.013)$ & 0.10 & 0.9190 \\
\hline & & Slope $\mathrm{L}: \mathrm{D}$ : Average Temperature & $-0.018(0.011)$ & -1.68 & 0.0920 \\
\hline & \multirow{5}{*}{$\begin{array}{c}\text { P2 (negative } \\
\text { binomial) }\end{array}$} & Intercept & $4.678(0.010)$ & 481.07 & $<0.0001$ \\
\hline & & Length & $0.123(0.011)$ & 11.41 & $<0.0001$ \\
\hline & & Average Temperature & $0.035(0.010)$ & 3.40 & 0.0007 \\
\hline & & Slope $L: D$ & $-0.023(0.010)$ & -2.25 & 0.0240 \\
\hline & & Slopel:D: Average Temperature & $-0.005(0.009)$ & -0.55 & 0.5600 \\
\hline
\end{tabular}


Table S9. Result from GLMs investigating temperature as only a direct driver of labial tooth number.

\begin{tabular}{|c|c|c|c|c|c|c|}
\hline Species & $\begin{array}{c}\text { Tooth Row } \\
\text { (Distribution) }\end{array}$ & & $\begin{array}{c}\text { Coefficient estimate } \\
\text { (std. error) }\end{array}$ & z-value & p-value & Pseudo-R ${ }^{2}$ \\
\hline \multirow[t]{6}{*}{ A. montanus } & \multirow{2}{*}{$\begin{array}{c}\text { A3 anterior } \\
\text { (negative } \\
\text { binomial) }\end{array}$} & Intercept & $4.590(0.015)$ & 298.50 & $<0.0001$ & \multirow[t]{2}{*}{0.229} \\
\hline & & Temperature & $0.073(0.015)$ & 4.72 & $<0.0001$ & \\
\hline & \multirow{2}{*}{$\begin{array}{c}\text { A3 posterior } \\
\text { (negative } \\
\text { binomial) }\end{array}$} & Intercept & $4.632(0.231)$ & 200.10 & $<0.0001$ & \multirow[t]{2}{*}{0.209} \\
\hline & & Temperature & $0.110(0.023)$ & 4.72 & $<0.0001$ & \\
\hline & \multirow{2}{*}{$\begin{array}{l}\text { P2 (negative } \\
\text { binomial) }\end{array}$} & Intercept & $4.567(0.019)$ & 242.09 & $<0.0001$ & 0.178 \\
\hline & & Temperature & $0.080(0.019)$ & 4.20 & $<0.0001$ & \\
\hline \multirow[t]{6}{*}{ A. truei } & \multirow{2}{*}{$\begin{array}{c}\text { A3 anterior } \\
\text { (negative } \\
\text { binomial) }\end{array}$} & Intercept & $4.670(0.010)$ & 486.18 & $<0.0001$ & \multirow[t]{2}{*}{0.170} \\
\hline & & Temperature & $0.055(0.010)$ & 5.72 & $<0.0001$ & \\
\hline & \multirow{2}{*}{$\begin{array}{l}\text { A3 posterior } \\
\text { (negative } \\
\text { binomial) }\end{array}$} & Intercept & $4.755(0.013)$ & 355.31 & $<0.0001$ & \multirow[t]{2}{*}{0.179} \\
\hline & & Temperature & $0.078(0.013)$ & 5.82 & $<0.0001$ & \\
\hline & \multirow{2}{*}{$\begin{array}{l}\text { P2 (negative } \\
\text { binomial) }\end{array}$} & Intercept & $4.683(0.013)$ & 358.89 & $<0.0001$ & \multirow[t]{2}{*}{0.170} \\
\hline & & Temperature & $0.074(0.013)$ & 5.63 & $<0.0001$ & \\
\hline
\end{tabular}




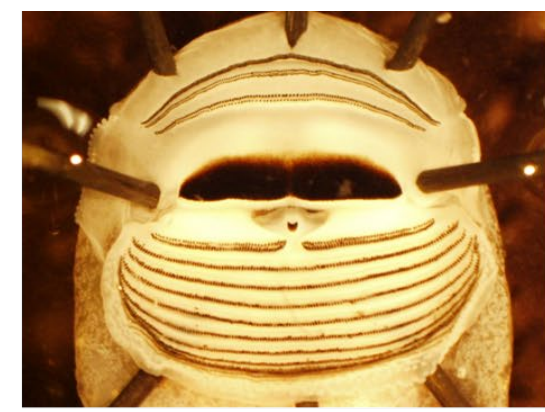

Full View

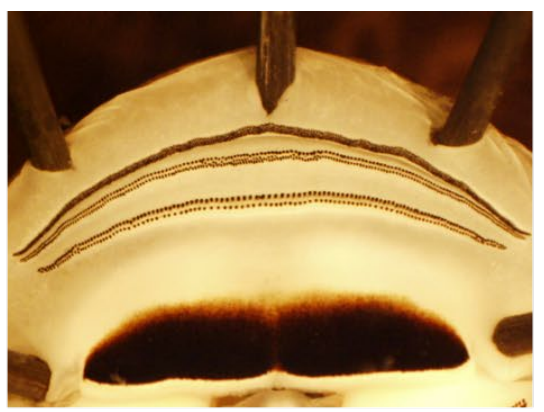

Anterior View

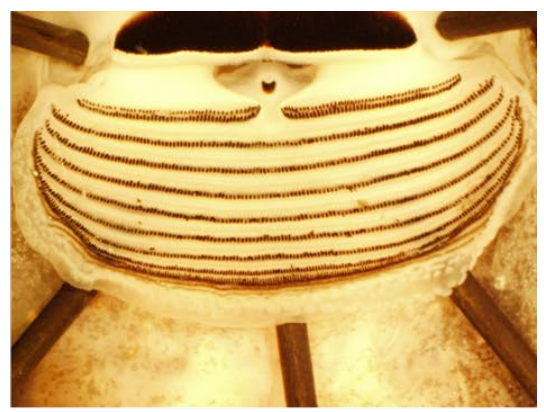

Posterior View

Figure S1. Example of photographs taken of labial tooth rows for each specimen. This particular specimen is from Lower Lost Horse, Montana (Ascaphus montanus). Photographs were taken using an Olympus SZX10 scope. 
bioRxiv preprint doi: https://doi.org/10.1101/2020.04.06.027664; this version posted January 27, 2021. The copyright holder for this preprint (which was not certified by peer review) is the author/funder, who has granted bioRxiv a license to display the preprint in perpetuity. It is made available under aCC-BY-NC-ND 4.0 International license.

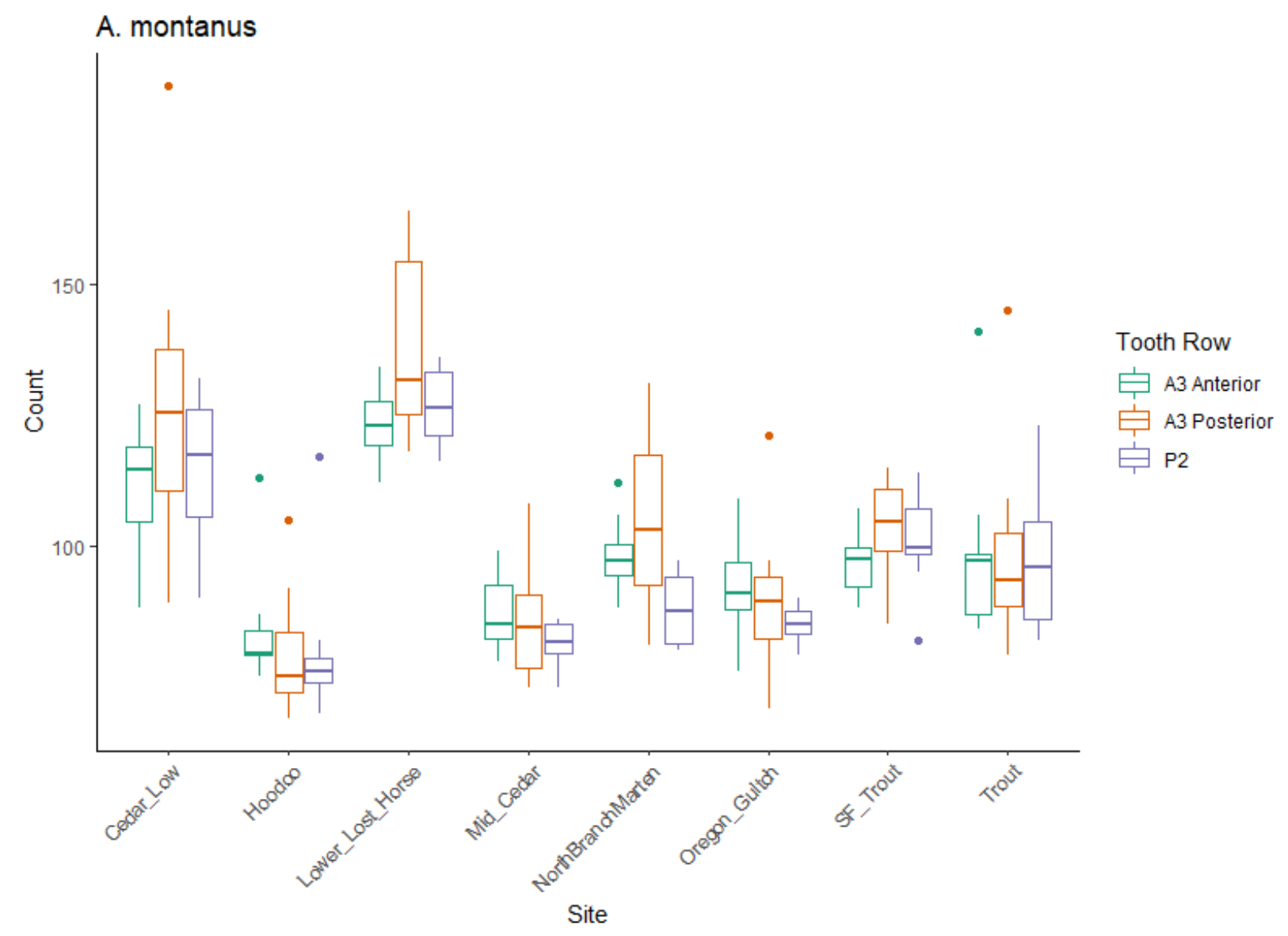

Figure S2. A. montanus population variation in labial tooth numbers across tooth rows. 


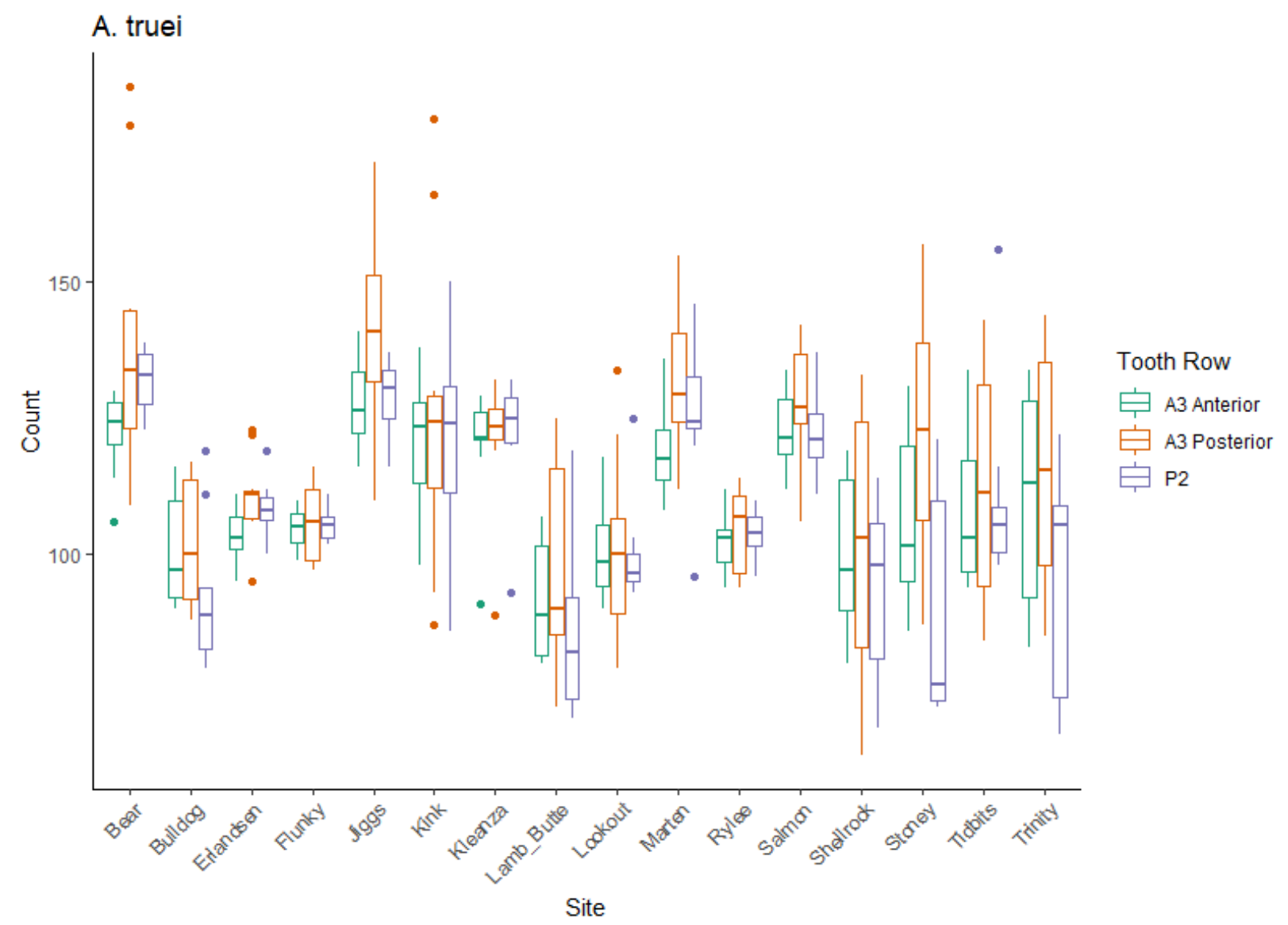

Figure S3. A. truei population variation in labial tooth numbers across tooth rows. 